\title{
Placement of vertebral screws for spinal stabilization and distraction in a dog with disc- associate cervical spondylomyelopathy: case report
}

[Uso de parafusos vertebrais para distração e estabilização espinhal em um cão com espondilomielopatia cervical disco-associada: relato de caso]

\author{
P.V.T. Marinho ${ }^{1}$, A.S. Macedo ${ }^{2}$, C.R.A. Ferrigno ${ }^{2}$, I.S. Dal-Bó ${ }^{2}$, F. Paes ${ }^{2}$, \\ T. Bregadioli ${ }^{2}$
}

${ }^{1}$ Instituto Federal de Educação, Ciência e Tecnologia do Sul de Minas Gerais - Muzambinho, MG

${ }^{2}$ Universidade de São Paulo - São Paulo, SP

\begin{abstract}
A 10-year-old male Rottweiler was evaluated for a 2-month history of recurrent forelimb weakness. Neurologic examination revealed proprioceptive ataxia, tetraparesis and moderate cervical pain. Diskassociated cervical spondylomyelopathy (CSM) with static lesion at C3-4 was diagnosed based on magnetic resonance imaging $(\mathrm{MRI})$. The dog was surgically treated by a ventral slot procedure and distraction-stabilization of the vertebral bodies through insertion of vertebral screws with transverse connective bars. The patient had favorable clinical outcome. Neurologic assessment performed 120 days after surgery showed absence of neurologic defects. Radiographic assessment performed at the same time indicated adequate spinal cord decompression although vertebral fusion was not achieved. To the authors' knowledge, this is the first case of distraction-stabilization with vertebral (pedicle) screws to treat CSM in a dog. The treatment was well tolerated with no complications and excellent outcome and can be a viable option for this condition.
\end{abstract}

Keywords: nervous system, spinal cord, stabilization, canine

\section{RESUMO}

Um cão, macho, adulto, Rotweiller de 10 anos de idade, foi atendido com histórico de claudicação do membro torácico esquerdo com evolução para fraqueza havia aproximadamente dois meses. Ao exame neurológico, observou-se ataxia proprioceptiva nos quatro membros e dor cervical moderada. Mediante ressonância magnética, espondilomielopatia cervical disco-associada com a característica estática da compressão C3-C4 foi diagnosticada. Realizou-se cirurgia descompressiva por meio de slot ventral e estabilização-distração com o uso de parafusos vertebrais e barras conectoras. O paciente apresentou evolução clínica favorável do quadro. A evolução foi progressiva e, no último retorno, 120 dias após a cirurgia, não apresentou nenhum déficit neurológico ou sinal de falha do implante nas imagens radiográficas; no entanto, não foi evidenciada fusão vertebral. Pelo conhecimento dos autores, esse é o primeiro relato de EMC disco-associada tratada por distração e estabilização com parafusos vertebrais (pediculares) em um cão. A fixação espinhal por meio do uso de parafusos vertebrais foi uma alternativa viável no caso apresentado.

Palavras-chave: sistema nervoso, medula espinhal, estabilização, canino

\section{INTRODUCTION}

The use of implants to obtain rigid internal stabilization has been advocated for the treatment of several diseases of the canine cervical vertebrae (Koehler et al., 2005; Steffen et al.,
2011) and a wide variety of implants have been applied, each with its advantages and disadvantages (Fitzpatrick and Fingeroth, 2014).

Placement of pedicle screws is a routine treatment for various disorders that promote vertebral instability in humans or when spinal

Recebido em 19 de outubro de 2016

Aceito em 6 de fevereiro de 2018

E-mail: paulo.veter@gmail.com 
fusion is required for the cervical, thoracic or lumbar spine (Smolders et al., 2012). It is possible to find in the literature several ex vivo biomechanical studies (Meij et al., 2007) as well as surgical reports (Smolders et al., 2012) that describe lumbosacral stabilization after decompressive surgery with efficient outcome using pedicle screws (Meij et al., 2007; Smolders et al., 2012; Zindl et al., 2014). As in the dog, the anatomical aspects of the vertebrae are different from those observed in the human anatomy, except for the lumbosacral spine, the screws should be applied to the vertebral bodies instead of the pedicles, so in the present study the implants were called "vertebral screws". To the author's knowledge there is no other report of placement of vertebral screws with connective rods in the canine cervical spine for treatment of disk-associated cervical spondylomyelopathy.

\section{CASE REPORT}

A 10-year-old intact male Rottweiler was evaluated for a 2-month history of progressive gait dysfunction. Physical and orthopedic examination showed no abnormalities. Neurologic examination revealed ataxia of all limbs with marked paresis of the left thoracic limb, proprioceptive positioning deficits and diminished hopping response in all four limbs. The other segmental reflexes were normal to increased in all limbs, the dog had moderate neck pain and intact cranial nerves. Survey radiographs performed under general anesthesia revealed intervertebral disc narrowing between C3-4 (Figure 1).

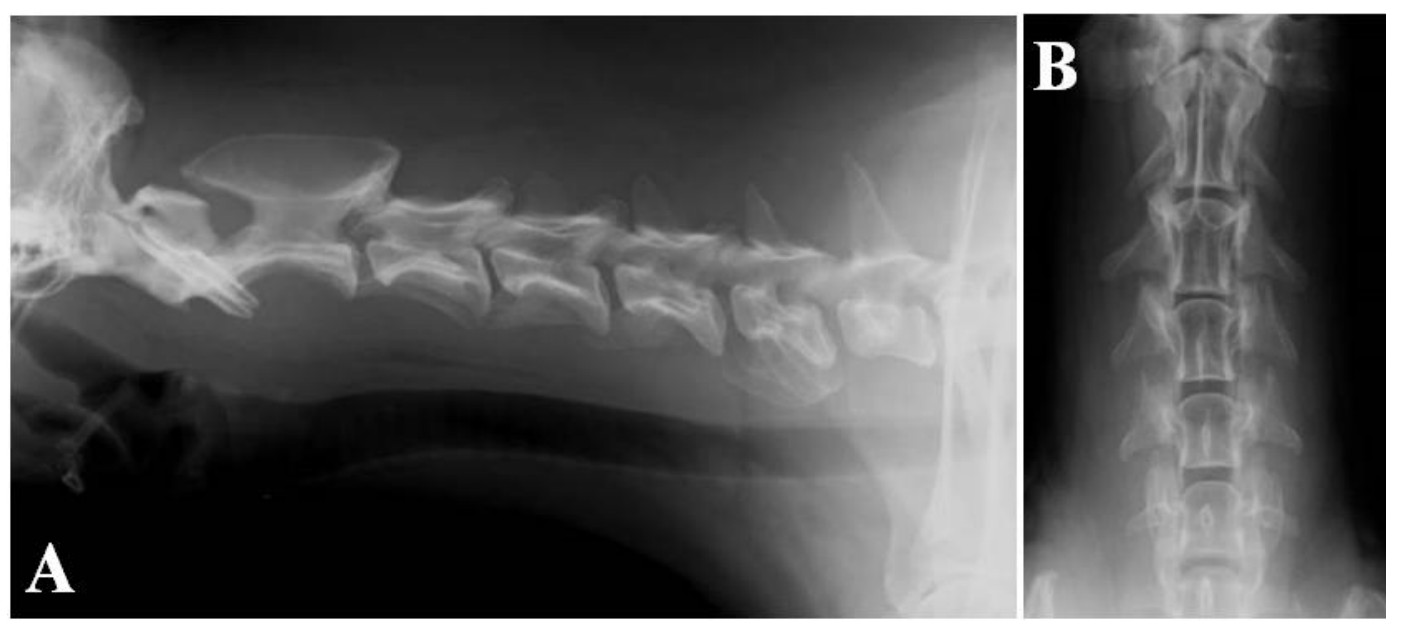

Figure 1. Radiographic image of the cervical spine displaying shortening of the C3-4 intervertebral space in lateral (A) and ventrodorsal (B) projections.

There was no improvement after 15 days of medical management with non-steroidal antiinflammatories drugs (NSAIDS) and restricted activity. There was neurologic worsening and the dog presented nonambulatory tetraparesis and severe neck pain. Routine blood analysis and biochemistry were within normal range and electrocardiography was normal. Cerebrospinal fluid analysis revealed elevated protein level. Magnetic resonance imaging (MRI) revealed ventral spinal cord compression at C3-4 level (Figure 2). Dynamic radiographic assessment showed a static lesion. Disk-associated cervical spondylomyelopathy (CSM) with static lesion at C3-4 was diagnosed. 


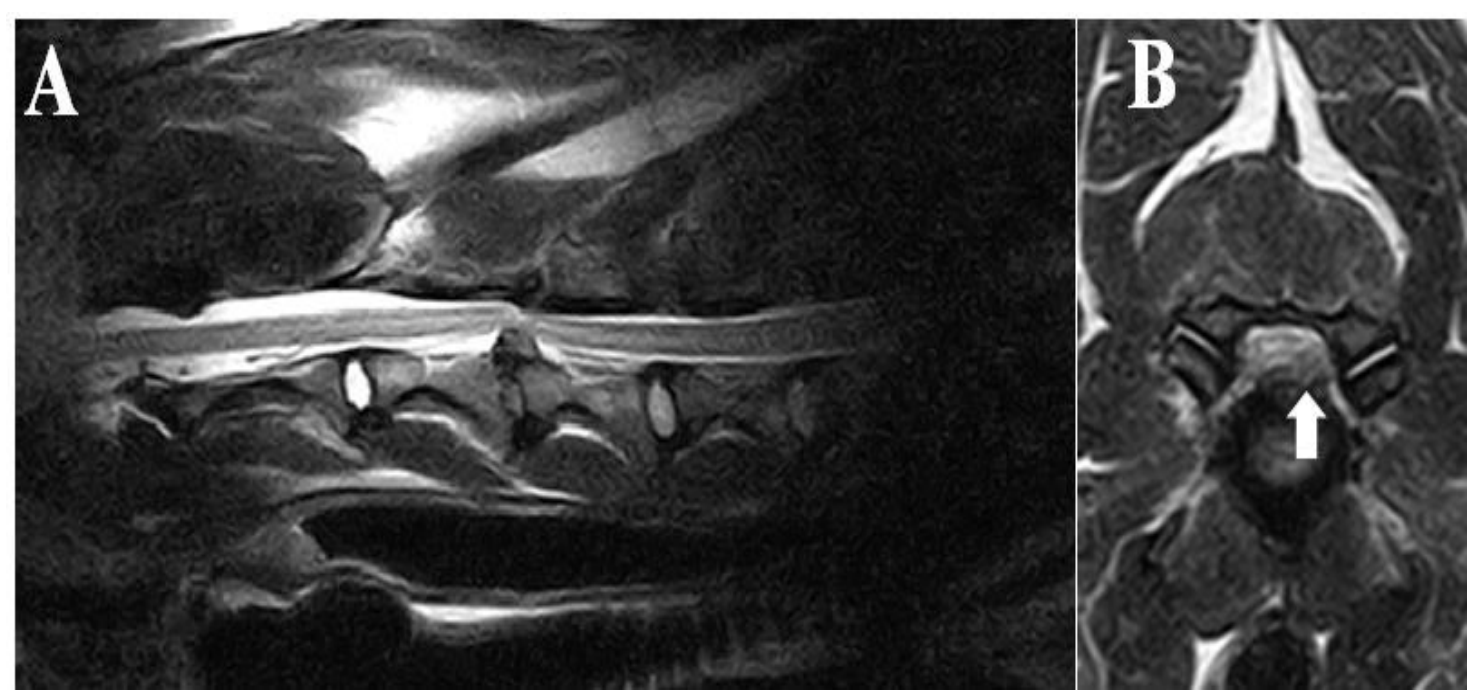

Figure 2. Pondered T2 Magnetic Resonance Image (MRI) displaying spinal cord compression at the C3-4 level in sagittal view (A) and left lateralized protrusion of disk material at the level of the intervertebral foramen $(\mathrm{B})$.

Surgical decompression of the spinal canal and posterior distraction-stabilization with vertebral screws were performed. During the ventral slot procedure performed after the intervertebral disk was fenestrated the surgeon noted that the nucleus pulposus was not degenerated and identified that the vertebral level approached was incorrect (C4-5), so the procedure was therefore repeated in the proper vertebral level (C3-4).

After the slot was created, a great amount of fibrous material was removed from the spinal canal. Then the vertebral screws were placed to maintain the left intervertebral foramen opened, reducing nerve root compression. A $2.7 \mathrm{~mm}$ monocortical titanium screw was inserted into the right side of each vertebral body $(\mathrm{C} 3, \mathrm{C} 4$ and $\mathrm{C} 5)$ and $\mathrm{C} 3$ and $\mathrm{C} 4$ received screws on the left side. The screws were inserted from lateral to medial direction in the caudal metaphyseal region of each vertebral body, with parallel drilling to enable placement of a titanium rod between the cups of each vertebral screw. Depth was measured while drilling based on the drill bit length when it reached the trans cortex. Two $3.5 \mathrm{~mm}$ parallel titanium rods were positioned and fixed to the correspondent screws. Once the rods fit perfectly into the vertebral screws, all counter torque locking sleeves were applied and locked after vertebral distraction was achieved with a specific bone distractor (Figure $3 \mathrm{~A} \mathrm{e} \mathrm{B}$ ).

The screws were placed without spinal canal invasion and accurate positioning of implants was confirmed by postoperative radiographs in lateral (Figure 4A) and ventrodorsal (Figure 4B) projections.

Neurologic status improved $95 \%$ in the owner's opinion 10 days after surgery. Neurologic assessment showed mild proprioceptive ataxia and mild proprioceptive deficits (observed only on the left forelimb) without pain at palpation.

There was progressive improvement 30 days after surgery without gait dysfunction although mild proprioceptive deficits were still present on the left forelimb. Neurological status at 90 days postoperatively was normal without any deficit, even though radiographic assessment did not display bone fusion at C3-4 intervertebral space and there was discrete loss of vertebral distraction.

Six months after surgery the patient remains stable without neurological changes and radiographic images showed bone growth only in the ventral slot area. 


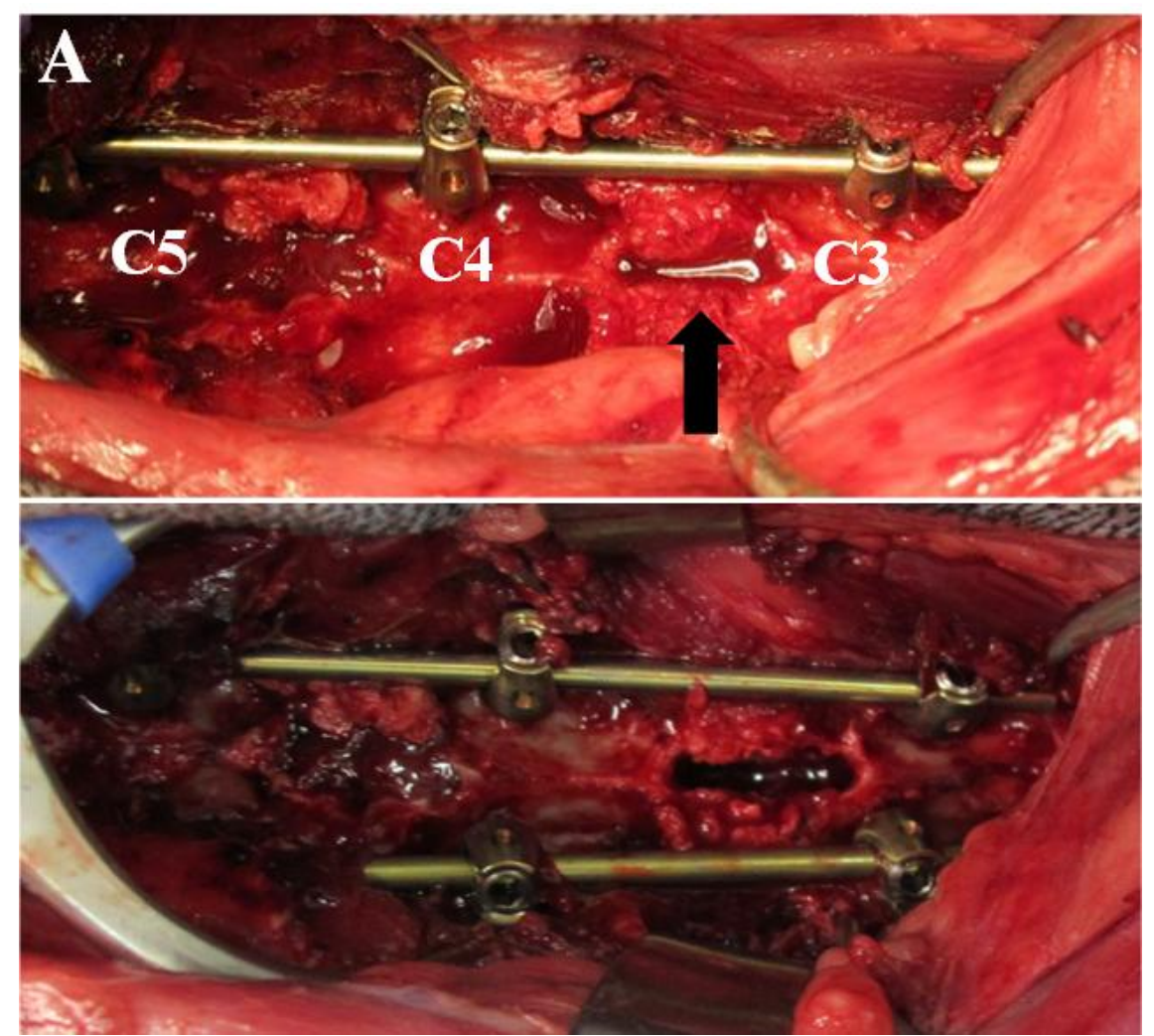

Figure 3. Transoperative photographic image of the insertion of the vertebral screws into the cervical vertebral bodies. A. Note the C3-4 ventral slot (arrow), the unilateral placement of vertebral on the left side of the $\mathrm{C} 3, \mathrm{C} 4$ and $\mathrm{C} 5$ vertebral bodies and placement of the connective rod. At this point the counterscrews applied to $\mathrm{C} 4$ and $\mathrm{C} 5$ were tightened but the $\mathrm{C} 3$ counter-screw remained loose, keeping only the connective rod attached. B. Note complete placement of the apparatus by adding a screw-rod set and rod on the left side of $\mathrm{C} 3$ and $\mathrm{C} 4$ vertebral bodies. At that moment the referent $\mathrm{C} 4$ counter screw was completely tight, letting the $\mathrm{C} 3$ loose. With the aid of specific distractor that was perfectly coupled to the interconnecting bar, intervertebral distraction between $\mathrm{C} 3$ and $\mathrm{C} 4$ of approximately $3 \mathrm{~mm}$ was performed, followed by immediate tightening of the $\mathrm{C} 3$ counter screws.

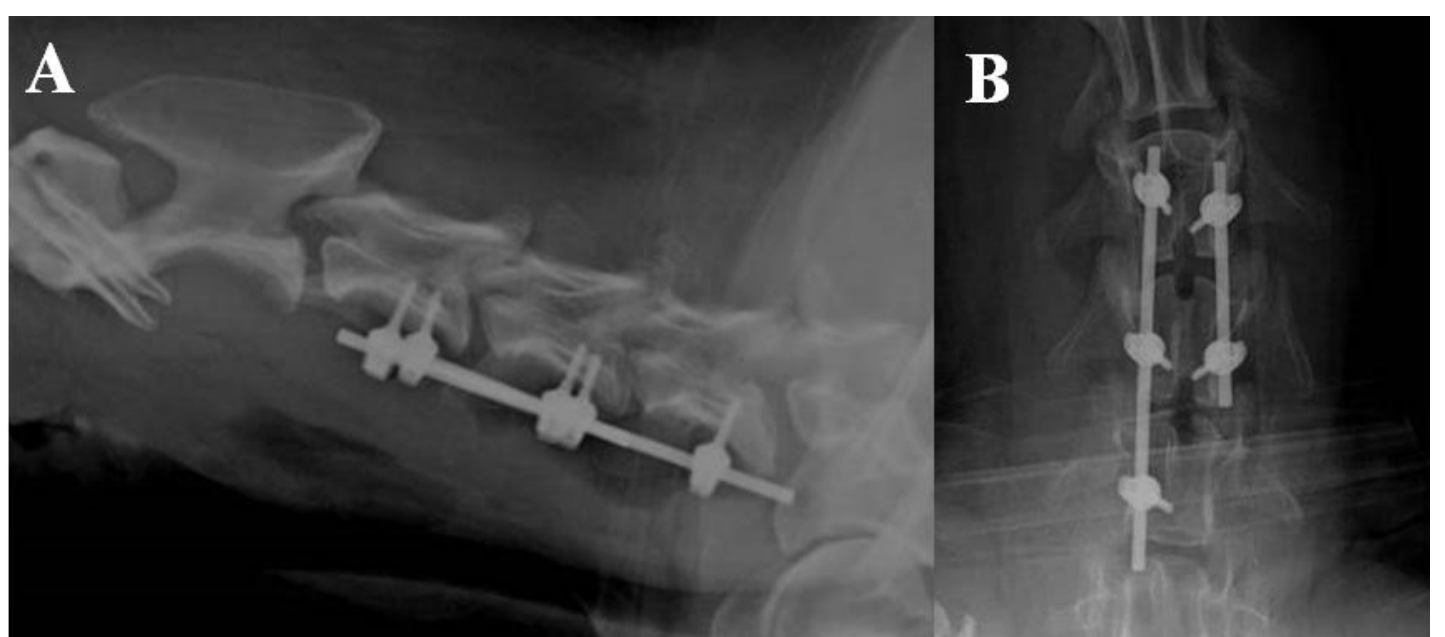

Figure 4. Radiographic image of the cervical spinal fixation apparatus by use of vertebral screws in lateral (A) and ventrodorsal (B) projections. 


\section{DISCUSSION}

Spinal fractures and luxation are the most common conditions that need surgical stabilization (Sturges and Lecouteur, 2003) but distraction and stabilization are also routinely required in cases of cervical spondylomyelopathy (Fitzpatrick et al., 2015).

This paper described a case of disk-associated cervical spondylomyelopathy irresponsive to traction. Direct decompression could not be completely achieved trough the ventral slot approach due to the type of lesion. For such reasons, the author chose to distract the vertebrae to extend the intervertebral foramen and relieve nerve root compression. Furthermore, the chronically compressed spinal cord may become symptomatic due to the occurrence of associated dynamic forces, in addition to the static compressive lesion.

It is possible that removal of the static compression, without providing stabilization could cause clinically significant instability, which could result in transient or permanent neurologic impairment. In contrast, surgical stabilization can produce indirect decompression by the reduction of the dynamic forces resulting in gradual regression of the soft tissue's hypertrophy over time (Solano et al., 2015). Both distraction and stabilization can be potentially beneficial. Distraction provides immediate nerve root and spinal cord decompression and stabilization promotes bone union or fibroosseous ankylosis of adjacent vertebrae (Fitzpatrick and Fingeroth, 2014).

Several techniques have been described to promote distraction and vertebral stabilization (Fitzpatrick and Fingeroth, 2014). However, there is no other report of vertebral screws and connecting rods with such purpose in the canine cervical spine. This technique was easily applied and allowed spinal distraction by adjustment of the fixing screws on the titanium rod (Smolders et al., 2012).

Biomechanically, pedicle screws and rod connector bars resemble locking plates because they act as internal fixators in a rigid screw-rod system, that provides angular stability that does not rely of the bone/implant friction, but on the screw/rod interface contact (Mckee, 2009).
Screw angulation requires greater fixation strength. The authors feel that screws of larger diameter and in greater amount, could have been used to increase the apparatus strength enhancing chances of achieving bone fusion without complications. The implant's large working area distributed stresses evenly but also allowed micromovement due to relative stability in the intervertebral space, which may have significantly interfered with achieving bone fusion in this case (Perren, 2002).

In the present report the authors decided to apply monocortical screws because the application of bicortical screws have a high penetration rate in the spinal canal. In a study of placement of pins associated to polymethylmethacrylate (PMMA), the percentage misplaced pins that penetrated vital structures was $57 \%$, which is a high occurrence (Koehler et al., 2005). In terms of stability, a biomechanical study performed by Hettlich et al., (2013) compared the use of monocortical screws with bicortical positive profile threaded pins for fixation of the cervical spine of dog cadavers. Fixation with monocortical screws was biomechanically equivalent to bicortical fixation.

Another important factor that directly affects the stability is the use or not of intervertebral spacers associated with supplementary fixation. According to Hettlich et al. (2014) adding an intervertebral spacer increases significantly the construction's rigidity when fixation was performed by use of monocortical screws and PMMA. In our case, the absence of spacers did not affect clinical outcome. However, slight loss of distraction that was observed in radiographic images during long-term follow up could have been minimized by use of spacers.

\section{CONCLUSION}

Ventral slot associated with distraction and vertebral fixation with vertebral screws was a viable alternative to treat disk-associated CSM with nerve root compression. Further studies are essential to biomechanically validate the proper width, recommended number of screws and rod connector bars, and to determine the correct screw's distance and the need for interconnects between the rod bars. Long-term clinical trials are also required in a great number of patients to strongly allow its routinely use and establish 
advantages and disadvantages compared to other techniques.

\section{REFERENCES}

FITZPATRICK， N.; FINGEROTH， J.M. Is "Wobbler" disease related to disc disease? In: FINGEROTH, J.M.; THOMAS, W.B. (Eds.). Advances in intervertebral disc disease in dogs and cats. Iowa: Wiley, 2014. p.50-66.

HETTLICH, B.F.; ALLEN, M.J.; GLUCKSMAN, G.S. et al. Effect of an intervertebral disk spacer on stiffness after monocortical screw/polymethylmethacrylate fixation in simulated and cadaveric canine cervical vertebral column. Vet. Surg., v.43, p.988994, 2014.

HETTLICH, B.F.; ALLEN, M.J.; PASCETTA, D. et al. Biomechanical comparison between bicortical pin and monocortical screw/polymethylmethacrylate constructs in the cadaveric canine cervical vertebral column. Vet. Surg., v.42, p.693-700, 2013.

KOEHLER, C.L.; STOVER, S.M.; LECOUTEUR, R.A. et al. Effect of a ventral slot procedure and of smooth or positive-profile threaded pins with polymethylmethacrylate fixation on intervertebral biomechanics at treated and adjacent canine cervical vertebral motion units. Am. J. Vet. Res., v.66, p.678-687, 2005.

MCKEE, W.M. SOP and spines. In: SPRING SCIENTIFIC MEETING OF THE BRITISH VETERINARY ORTHOPAEDIC ASSOCIATION, 2009, Birmingham. Proceedings... Birmingham: VCOT, 2009. p.13-19.
MEIJ, B.P.; SUWANKONG, N.; VAN DER VEEN, A.J. et al. Biomechanical flexionextension forces in normal canine lumbosacral cadaver specimens before and after dorsal laminectomy-discectomy and pedicle screw-rod fixation. Vet. Surg., v.36, p.742-751, 2007.

PERREN, S.M. Evolution of the internal fixation of long bone fractures. The scientific basis of biological internal fixation: choosing a new balance between stability and biology. J. Bone Jt. Surg., v.84, p.1093-1110, 2002.

SMOLDERS, L.A.; VOORHOUT, G.; VAN DE VEN, R. et al. Pedicle screw-rod fixation of the canine lumbosacral junction. Vet. Surg., v.41, p.720-732, 2012.

SOLANO, M.A.; FITZPATRICK, N.; BERTRAN, J. Cervical Distraction-Stabilization Using an Intervertebral Spacer Screw and Stringof Pearl (SOPTM) Plates in 16 Dogs With DiscAssociated Wobbler Syndrome. Vet Surg., v.44, p. $627-641,2015$.

STEFFEN, F.; VOSS, K.; MORGAN, J.P. Distraction-fusion for caudal cervical spondylomyelopathy using an intervertebral cage and locking plates in 14 dogs. Vet. Surg., v.40, p.743-752, 2011.

STURGES, B.K.; LECOUTEUR, R.A. Vertebral fractures and luxations. In: SLATTER, D. Textbook of small animal surgery. 3.ed. Philadelphia: Elsevier, 2003. p.1245-1261.

ZINDL, C. et al. Motion capture analysis of the mechanical performance of a novel pedicle screw-rod fixation system for the canine lumbosacral joint. Vet. Surg., v.43, p.E117-E118, 2014. 